\title{
TIEMPO SAGRADO EN LAS CULTURAS INCÁSICA Y AZTECA ${ }^{1}$
}

Sacred time in the Incasic and Aztec Cultures

María Eugenia Ugarte Facultad de Artes Universidad de Chile mauja123@hotmail.com

\begin{abstract}
Allá, en la raíz interior del cielo, es donde impera el que da la vida, ¡llorad, lamentaos!

¿Dónde perecerán sus siervos?
\end{abstract}

(Poema azteca)

De los pueblos aborígenes de América, es el azteca el que con mayor rigor cumple su destino bajo el imperio de lo sagrado.

Es esto lo que otorga plenitud a la vida y es también lo que le pone fin. Lo misterioso, lo sobrenatural orientan al hombre, lo purifican, le dan el poder, la sabiduría, la virtud y lo conducen implacablemente hacia las potencias de los dioses que los aniquilan.

Para el azteca, lo sagrado es voluntad de vivir, pero también, voluntad de muerte, puesto que ésta lleva en sí el concepto de vida eterna. La muerte es el mejor modo de revitalizar a los dioses y al pueblo.

En el hombre encuentran los dioses una fuente de vida; el hombre, en cambio, recibe la muerte de mano de los dioses, pero de esta muerte surge el pueblo fortalecido.

Este ciclo, repetido continuamente, presenta al hombre como colaborador de la divinidad:

\footnotetext{
${ }^{1}$ Publicado en VIII Jornadas Interdisciplinaria de Religión y Cultura. Páginas 57 - 64
} 
éste nació gracias al trabajo de los dioses y tiene que corresponder ofreciéndoles su sangre como alimento sagrado: El Chalchihualt o líquido preciosos, otorgador de vida, oculto en el corazón humano.

Es un universo regido por lo sobrenatural que mira siempre hacia la muerte, concebida sin un sentido moral. Después de ella no hay un cielo o un infierno donde se premie o se castigue.

El transmundo azteca está organizado por los puntos cardinales y lo vertical y lo horizontal.

Hay un paraíso oriental y uno occidental, regidos por el Sol, donde van los guerreros muertos en combate; cuatro años pasan en compañía del sol y luego vuelven a la tierra convertidos en pájaros de hermoso plumaje. También van al paraíso las mujeres muertas en el parto, los ahogados y los leprosos. Los demás van con Mitlantecutle. Después de pasar trabajos y pruebas mágicas, se liberan y desaparecen para siempre.

La situación del azteca en la otra vida está normada por la forma de morir, o bien, por los hábitos u oficios que ha desempeñado en este mundo.

La concepción sagrada de la vida y la muerte hacen de la religión un hecho social; ésta reglamenta la existencia de los individuos desde su nacimiento, determinando las relaciones con sus semejantes y con los dioses.

Los sacerdotes eran la casta que relacionaba al pueblo con la divinidad; dirigían el ritual e instalaban la presencia del misterio en la conciencia azteca.

No es de extrañar que el arte de esta civilización estuviera impregnado de religiosidad y de contradicciones como la de la vida y la muerte, la expresión subjetiva y la representación real del entorno.

Un cronista del siglo XVI señalaba la evidencia de una antítesis de esta categoría, afirmando que "los indios avezados y honestos, eran a la vez, desenfrenados y sanguinarios". 
La exacerbación de esta dualidad estalla en el arte, especialmente en la escultura: La madre de los dioses Coatlicue, reúne en sí los principios fecundos de vida y muerte. Es representada en la piedra con un collar de corazones humeantes y manos cortadas, serpientes como falda, y garras que agreden a los hombres.

Tezcatlipoca, el del espejo humeante y múltiple poder, nos lo muestran sus imágenes con una deformidad humana: es cojo.

Abstracción y naturaleza queriendo aunarse en lo sagrado, materializando el misterio que preside el destino del hombre náhuatl.

Tal vez, algo de este misterio podamos develar, observando la arquitectura y la escultura azteca que, a pesar de la estrecha unión que hay entre ambas, están realizadas con distinto sentido: En la arquitectura, predomina una intención de verticalidad, orientación de inmovilidad y permanencia, que lleva a relacionarla con muerte y eternidad. La escultura en cambio, se mueve en forma horizontal y reiterativa, adosándose a los muros como venas, tendones y nervios; es lo que anima el espacio sagrado, lo que revela lo humano y su sumisión a los dioses. La arquitectura sostiene a lo divino, la escultura le da vida, ella insiste en sí misma, regresa a su propio principio.

Quetzalcoalt, es uno de los motivos más recurrentes de la escultura azteca, la serpiente emplumada que muere y de sus cenizas nace la estrella Venus, que retorna cada día. Lo sagrado vuelve a lo sagrado.

Es la creatividad del hombre al servicio del mito. Ritual en que la existencia misma se ha convertido en un solo ciclo de vida y muerte y, ambas son el umbral del espacio sagrado.

\section{TEMPLO MAYOR}

El espacio ritual de Tenochtitlán 
Según relatos legendarios, las tribus aztecas, después de un largo peregrinar, se asentaron en una isla, en el medio del lago Texcoco, en el valle de México.

Escogen este lugar, porque al llevar ven una serie de señales que coinciden con lo predicho por su dios ancestral, Huitzilopochtli.

Estos símbolos tienen dos orígenes: unos son tomados de los toltecas, cuya cultura es anterior a la azteca, pero relacionada con ésta, puesto que en tiempos lejanos, en el lugar de origen del pueblo azteca, la mítica Aztlán, éstos eran tributarios de los toltecas a los que admiran y consideran un ejemplo de grandiosidad.

Los aztecas intentan legitimarse como descendientes de estos toltecas, apoderándose de su simbología. Es así como, al llegar al lago, según la leyenda, lo primero que ven es una corriente de "agua roja y azul, con peces, ranas y plantas blancas", símbolos éstos relacionados con la llegada de los toltecas a su ciudad sagrada, Chilula, en épocas pasadas.

Los aztecas sacralizan su asentamiento y validan su ascendencia por medio de estos signos trascendentes.

La otra simbología que interviene en la ciudad fundacional azteca proviene de la profecía de Huitzilopochtli: "allí donde vean el águila devorando la serpiente, parada en un nopal, allí os quedaréis".

Reunir la tradición de la prestigiosa cultura tolteca con la ancestral de su propia tribu les permite asentar su ciudad sobre principios sólidos.

En el plano de lo mítico, los aztecas establecen "el Centro" en el nuevo lugar.

Ellos concebían un "centro" del espacio social y un "centro" cosmológico de la tierra.

De esta manera separaban el espacio sagrado del profano.

En la fundación de la ciudad de Tenochtitlán, construirían el Templo Mayor, en el lugar 
simbólico del águila en el nopal, la señal de su Dios, convirtiéndose en el centro del universo azteca, en el "ombligo del mundo" (M. Eliade), lugar donde se unen los tres niveles de la cosmovisión de este pueblo: los cielos, la tierra y el inframundo.

Ubicado "el Centro", se construye el Templo Mayor, dividiendo el espacio en cuatro partes.

Un relato de Fray Diego Durán (Historia de Nueva España e Islas de Tierra firme, 1867,

México City), dice lo siguiente:

"Aquella noche que los mexicanos acabaron de reparar la ermita, donde su dios estaba, teniendo ya gran parte de la laguna cegada y hecha ya la plancha y asiento para hacer casas, habló Huitzilopochtli a su sacerdote o ayo y dijo: "Dí a la congregación mexicana que se dividan los señores, cada uno con sus parientes, amigos o allegados, en cuatro barrios principales, tomando en medio la casa que para mi descanso habéis edificado y cada parcialidad edifique en su barrio a voluntad".

Se crea, así, el "espacio sagrado", lugar de los templos, recinto ceremonial de la ciudad de Tenochtitlán y el "espacio profano", recinto habitacional urbano.

Los códices, escritura pictográfica mesoamericana que contenía los aspectos religiosos y civiles de estas sociedades, muestran en varias ocasiones una composición de carácter cosmológico, cuyo diagrama nos permite visualizar cómo la disposición de una ciudad corresponde a los conceptos y símbolos de orden que tenían del universo.

El Templo Mayor, como representante del centro fundamental de este mundo, contiene en su arquitectura esta cosmovisión: el nivel terrestre está representado por la plataforma basal donde se eleva el templo. Sobre éste y en forma piramidal hay cuatro cuerpos superpuestos y escalonados que corresponden al nivel celeste.

La plataforma superior está coronada por dos adoratorios dedicados al dios ancestral 
Huitzilopochtli y a Tlaloc, viejo dios de la lluvia, indicadores del dualismo cósmico de las creencias aztecas.

Los lados de la pirámide representan montañas sagradas: la del lado del templete de Huitzilopochtli es el cerro Coatepetl, montaña serpiente, donde el dios, según la tradición mítica, vence a sus enemigos. Esta leyenda cuenta que una vieja sacerdotisa que se ocupaba del templo dedicado a la diosa Madre Tierra, en la montaña Coatepetl, llamada Coatlicue, se encontraba barriendo, en el momento en que una plumita caía del cielo. Ella la guardó en su seno y esto hizo que concibiera mágicamente al dios Huitzilopochtli. Coatlicue tenía muchos otros hijos que, al enterarse de lo sucedido, se enfurecieron. Coyoltzauxque, la de los cascabeles en las mejillas y sus hermanos, los centzonhuiznahua (cuatrocientos hermanos) marcharon al cerro Coatepetl, para dar muerte a su madre por aquel embarazo que consideraban una ofensa.

Huitzilopochtli numen solar, dios de la guerra, que estaba en el vientre de su madre, le advierte a ésta que no se aflija, que él la defenderá y le pide que le diga solamente de qué lado vienen sus hermanos. Uno de los cuatrocientos, traicionando a los demás, le avisa el momento en que suben por la ladera del cerro y en ese instante ocurre el milagro: nace Huitzilopochüi, se atavía para la guerra y armado con la "serpiente de fuego", Xiuhcoalt, derrota a sus hermanos, captura a Coyoltzauxque, la decapita y su cuerpo es arrojado cerro abajo, desmembrándose. Huitzilopochili se paró triunfante en la cima de la montaña sagrada.

Huitzilopochili encarna al sol, Coyoltzauxque a la luna y deidades nocturnas, y los Centzonhuiznahua representan las innumerables estrellas.

Al fundar Tenochtitlán, los mexicanos reproducen aquella lucha cósmica: el Templo Mayor es "el cerro Templo"; el adoratorio de Huitrilopochtli, en lo más alto como el mito lo depara, Coyoltzauxque al pie del Templo, decapitada y destrozada.

Los sacrificios repetidos una y mil veces en el Templo Mayor no son otra cosa que la 
actualización de este mito; es la renovación de lo que hizo Huitzilopochtli con Coyoltzauxque: se inmola la víctima en la cima del templo y se le arroja escalinatas abajo, donde su cuerpo se desmembra.

El significado de estos sacrificios es revivir lo acontecido en un tiempo primordial: la lucha entre el sol y la luna, entre el día y la noche, entre la luz y las tinieblas.

El costado del templo que corresponde a Tláloc, dios del agua, es el Tonacateplt, o "cerro de los mantenimientos", representación simbólica referente a las montañas sagradas de donde proviene la lluvia.

Las ofrendas que se han encontrado en las excavaciones así lo confirman: las del lado del numen solar, dios guerrero Huüzilopochtli, son cuchillos de pedernal, cráneos tallados, esfinges de guerreros, relieves que representan a la Coyoltzauxque destrozada y también esculturas de la espada serpiente del fuego Xiuhcoalt.

En el lado del templo que corresponde a la montaña dedicada a Tláloc hay ofrendas de vasijas rituales decoradas con objetos relacionados con la agricultura, representaciones de relámpago y lluvia y muchos esqueletos de animales del mundo acuático.

Ya hemos dicho que el Templo Mayor era el Axis Mundi azteca, pero también el centro ceremonial en que se encuentra enclavado es considerado como "centro".

Este espacio sagrado es el arquetipo de la cosmovisión mexica: poseía cuatro puertas, cada una ubicada según los puntos cardinales, que permitían el acceso a cuatro calzadas coincidentes con los puntos norte, sur, este y oeste.

En este gran recinto nada estaba construido al azar: se podían contar 78 edificaciones ubicadas según un orden y una geometría cosmológicas.

Esto es así, puesto que en cada fundación de una ciudad se representa la creación del mundo. Después de los ritos de validación del lugar, el recinto es cerrado por una muralla 
circular o cuadrada cuyas cuatro puertas se abren a los cuadrantes del universo.

Richard Townsed, State and Cosmos in the Art of Tenochtitlán, dice:

"el principal recinto de Tenochtilán tenía una serie de pequeños santuarios al borde de la plaza ritual. Estos santuarios pertenecían a los cuatro barrios de la ciudad".

Era el conjunto, el espacio más crucial del imperio, así como el más sagrado, era en efecto un" microcosmos de la ciudad y un macrocosmos del universo". Tenochtitlán y su recinto ceremonial son los dos centros sagrados, uno dentro de otro.

Palacios, edificios dedicados a lo administrativo o a lo ritual, rodeaban el centro del centro; el Templo Mayor, símbolo de las dos montañas sagradas: la del mantenimiento (Tláloc) y la del héroe guerrero solar, Huitzilopochtli.

Esta dualidad en la concepción del mundo sacro está corroborada por una imagen que se ha encontrado en el centro del Templo Mayor; es una figura que representa al "Dios Viejo", considerado la encarnación de las fuerzas opuestas que mueven al universo: es el Tepellotle.

Tanto la arquitectura como esculturas, jeroglíficos, altares y monumentos, les hacían presente al pueblo mexica, en todo momento, la íntima relación de su imperio con las estructuras y fuerzas del mundo circundante.

\section{EL MONTE TLÁLOC}

Santuario de la renovación de la naturaleza

Ya hemos dicho que en la cultura azteca las representaciones plásticas, la arquitectura, el drama ritual, el entorno, están profundamente relacionados por el pensamiento simbólico, estableciéndose un diálogo vital constante entre ellos.

Las imágenes representativas de Tláloc, dios de la lluvia y de la fertilidad, son una metáfora

Cuadernos Judaicos ISSN: 0718-8749

Volumen Aniversario 50 años 
de la concepción del mundo que tiene esta civilización, a las que les asignan colores y formas pertenecientes al cielo, a la tierra y al agua.

Los ritos en homenaje a Tláloc se realizaban en varios lugares, tales como en las pirámides de Tenochtitlán, Texcoco y en las de otras ciudades. Pero nos referiremos a un templo situado en la cumbre de una montaña.

En él se celebraba el drama mítico de renovación de la naturaleza, cuyo ritual tomado de primigenias culturas, fue incorporado a las creencias religiosas aztecas y en el cual los reyes mexicas tenían un papel principal. Es en este ceremonial arquetípico donde se fundan las raíces de la monarquía azteca y la hacen suya antes de que fuera imperio.

A medida que conquistaban nuevos pueblos, iban también incorporando sus deidades a la religión azteca.

La interminable ronda de festividades y ritos cargados de contenido emocional e imaginativo actuaba como elemento aglutinador e integrador de ese pueblo diversificado.

Las diferentes etnias se aunaban por medio de prácticas y creencias que ya eran comunes y en un mismo lenguaje visual simbólico.

El Templo Mayor de Tenochtitlán y otros templos estaban conectados por rutas de peregrinación a lugares sagrados naturales y adoratorios, los que formaban una red geográfica mítica que designaba puntos de contacto con las divinidades. Unos de éstos, el templo dedicado a Tláloc, el que ya se ha nombrado, es primordial. Construido en la cumbre de la montaña, a 4.000 metros sobre el nivel del mar, punto de encuentro del cielo y la tierra, era escenario del antiguo ritual que realizaban los reyes aztecas durante el tiempo de sequía, época relacionada con la muerte. Este tiempo debía trocarse en lluvias y resurgimiento de la vida.

Fray Diego Durán da el siguiente relato:

Cuadernos Judaicos ISSN: 0718-8749

Volumen Aniversario 50 años 
"Luego el amaneciendo salían todos estos reyes y señores, con toda la demás gente y tomaban un niño de seis o siete años y metíanlo en una litera, por todas partes cubierto, que nadie lo biese y poníanlo en hombros de los principales... y llegados hasta el lugar del patio que llamaban Texacualco y llegados allí delante de la imagen del ídolo Tláloc mataban a aquel niño dentro de la litera que nadie lo beía.

Llegaba el rey y sacaba un rico aderezo para el ídolo y con su propia mano le ponía en la cabeza una corona de plumas ricas y le cubría con una manta, la más costosa que podía haber.

Luego el rey de Texcoco llevaba otro bestido de igual manera y si en algo se podía aventajar se aventajaba y así lo hacían todos los reyes.

Acabada la ceremonia, los sacerdotes que habían degollado aquel niño, con un hizopo rociabase con la sangre inocente al ídolo Tláloc y toda la comida".

Tradición que obedecieron los gobernantes, durante generaciones, puesto que el propósito era asegurar la vitalidad de la tierra, el orden y la continuidad de la sociedad.

Solo ruinas perduran del Templo de Tláloc, pero a través de algunos códices como el Borgia, su iconografía nos da un indicio de lo que pudo ser este espacio sagrado.

El recinto poseía un corredor con altas paredes que constituían el camino procesional que conducía al centro ceremonial; los participantes solo podían contemplar el lugar simbólico ahí presente. La separación del mundo exterior e interior era intencional.

El largo corredor que debían recorrer en procesión reyes y oficiantes antes de llegar a la cámara sagrada, bien podría considerarse como el camino hacia el útero de la montaña (creencia ésta basada en antiguas leyendas toltecas-chichimecas).

Poseía la cámara sagrada un pozo circular, esta circularidad la hacía asociar con la "Madre Tierra". 
"Era un lugar de ofrenda y comunión con ella y también con el corazón de la montaña" (Townsed).

Hay una palabra en náhualt que se usaba para designar lugares como el del Templo de Tláloc: "Teolt". Por su difícil traducción, los españoles lo interpretaron como "dios", "santo" y también "demonio".

Aparece a menudo asociado a los nombres de las deidades, a esculturas de dioses, a máscaras y a objetos de culto.

También se le relaciona con las fuerzas de la naturaleza y con todo lo incomprensible o extraordinario, como la inmensidad del mar, el sol, el rayo o a una montaña misteriosa. La empleaban, también, para referirse a la fuerza vital que en esta cosmovisión poseen todos los seres y objetos sagrados. Tal vez las palabras "mana", sobrenatural, sagrado, numinoso, nos pueden acercar a su significado.

El monte de Tláloc, en medio de montañas nevadas, con la presencia de sacrificios cruentos y de los oficios reales, sin lugar a dudas, poseía el "Teolt".

Un pueblo que vive en permanente contacto con lo sagrado, en donde todo tiene que ver con la divinidad y lo preternatural, ha creado un lenguaje metafórico con el que no se dirige a los hombres que son transitorios, sino a lo que ellos puedan ocultar de lo divino y eterno.

Por medio del culto a los dioses sacralizaban lo que les era esencial para su existencia. Al honrar a Tláloc y a Huitzilopochtli, lo que hacían era trasmutar el agua y la guerra en elementos consagrados.

\section{"La flor amarilla \\ abrió su corola \\ ella es nuestra madre; \\ la del rostro con máscara \\ que vino de Tamoachan.}

Cuadernos Judaicos ISSN: 0718-8749 
La flor amarilla floreció.

Ya nuestro Padre el Sol

se hunde ataviado de ricas plumas,

en una urna de piedras preciosas

y va como ceñido con collares de turquesas

entre policromas flores que sin cesar llueven". 